\title{
Ontogeny of Ghrelin, Obestatin, Preproghrelin, and Prohormone Convertases in Rat Pancreas and Stomach
}

\author{
PALLAVI WALIA, ALI ASADI, TIMOTHY J. KIEFFER, JAMES D. JOHNSON, AND JEAN-PIERRE CHANOINE
}

Endocrinology and Diabetes Unit [P.W., J.-P.C.], British Columbia Children's Hospital, Vancouver, British Columbia, V6H 3V4, Canada; Departments of Cellular and Physiological Sciences and Surgery [A.A., T.J.K., J.D.J.], University of British Columbia, Vancouver, British Columbia, V6T 1Z3, Canada

\begin{abstract}
The processing of preproghrelin in the stomach by prohormone convertase (PC) 1/3 produces ghrelin and possibly obestatin. In the neonate, the pancreas is also a major source of ghrelin. We compared the ontogeny of preproghrelin, ghrelin, obestatin, and PCs in the stomach and pancreas from rat embryos (day 21) and neonates (days 1, 6, 13, 21, and 28) by immunohistochemistry. In stomach, preproghrelin positive cells were present from embryonic day 21 and were in excess of ghrelin cells. The number of ghrelin positive cells progressively increased with age. When preproghrelin cells were immunoreactive for ghrelin, they were also immunoreactive for obestatin and PC1/3. In pancreas, we only found 0 to 2 preproghrelin positive cells per islet and each of these cells was also positive for ghrelin and obestatin. None of the ghrelin positive cells stained for insulin, but we observed ghrelin positive/glucagon negative and ghrelin positive/glucagon positive cells. Ghrelin positive cells contained PC1/3 or PC2. In summary, in stomach, an excess of preproghrelin positive cells compared with ghrelin/PC1/3 positive cells suggests that $\mathrm{PC} 1 / 3$ determines preproghrelin processing to ghrelin. In pancreas, the colocalization of PC1/3 or PC2 in ghrelin positive cells points to a role for both PCs in preproghrelin processing. (Pediatr Res 65: 39-44, 2009)
\end{abstract}

$\mathrm{G}$ hrelin is a 28 amino acid growth hormone releasing and orexigenic peptide secreted by the fundus of the stomach in adult humans and rodents (1). Ghrelin (amino acids 24 to 51) results from posttranslational processing of the 117 amino acid preproghrelin precursor protein by prohormone convertase (PC) 1/3 (2). It is secreted as acylated and desacyl ghrelin (3). The presence of an acyl chain on the Ser3 residue of ghrelin is necessary for activation of the growth hormone secretagogue receptor that mediates the orexigenic action of ghrelin at the hypothalamic level. Preproghrelin is also predicted to generate another 23 amino acid peptide named obestatin (amino acids 76 to 98). In contrast to ghrelin, obestatin was proposed to have anorexigenic properties (4).

The tissue localization of ghrelin differs in the fetal, neonatal, and adult rat. Concentrations of immunoreactive ghrelin are low in the fetal stomach and increase progressively to reach adult values by 3 to $4 \mathrm{wk}$. In contrast, the fetal pancreas

Received June 17, 2008; accepted August 13, 2008.

Correspondence: Jean-Pierre Chanoine, M.D., Ph.D., Endocrinology and Diabetes Unit, Room K4-212, British Columbia's Children's Hospital, 4480 Oak Street, Vancouver BC V6H 3V4 Canada; e-mail: jchanoine@cw.bc.ca

This work was supported in part by grant MOP 81291 of the Canadian Institutes of Health and Research (CIHR) [J.-P.C.]; CIHR, the Canadian Diabetes Association (CDA), the Michael Smith Foundation for Health Research (MSFHR), and the Juvenile Diabetes Research Foundation (JDRF) [T.J.K., J.D.J.]. contains elevated concentrations of ghrelin that decrease after birth and become almost undetectable by weaning (3). The regulation of ghrelin also seems to differ in the perinatal and adult periods, but it is not yet clear how this is achieved. In adult animals, plasma ghrelin concentrations increase with hypoglycemia and fasting. In contrast, we have shown that in rat fetuses, hypoglycemia secondary to maternal fasting did not affect plasma concentrations of total ghrelin (5). Pancreas ghrelin is emerging as a key player in the regulation of insulin secretion by the $\beta$-cell, suggesting that it may play an important role in glucose metabolism $(6,7)$. Recently, it was suggested that obestatin could promote pancreas $\beta$-cell survival (8) and, similar to the role of ghrelin in the pancreas, inhibit insulin secretion (9). However, the exact function of obestatin remains unclear (10).

In stomach, Zhu et al. (2) demonstrated that ghrelin results from processing of preproghrelin by $\mathrm{PC} 1 / 3$. However, in pancreas, $\mathrm{PC} 1 / 3$ plays a major role in proinsulin processing (11) but ghrelin positive cells have been reported to be colocalized mostly independently from insulin, in glucagon $\alpha$-cells (12) or in a new cell type called $\varepsilon$-cells $(13,14)$. Therefore, whether PC1/3 is also involved in the processing of ghrelin from preproghrelin in the pancreas is unknown (15). In addition, whether obestatin and ghrelin are present in the same cell types in the rat perinatal pancreas is also unclear. We have previously reported that obestatin concentrations were markedly lower than those of ghrelin in the perinatal period, a surprising finding considering that ghrelin and obestatin share the same propeptide (16). Recently, Gronberg et al. (17) demonstrated in humans that ghrelin and obestatin were present in the pancreas islet in the same cell type, consistent with the concept that preproghrelin processing would generate both ghrelin and obestatin.

We hypothesized that ghrelin, obestatin, and preproghrelin would colocalize in the pancreas as well as in the stomach and that different PCs would be involved in the processing of ghrelin in the stomach and pancreas. The objectives of this study were 1) to compare the ontogeny of preproghrelin, ghrelin, and obestatin in the rat pancreas and stomach by immunohistochemistry; 2) to clarify the identity of ghrelinsecreting cells in the perinatal pancreas; 3 ) to compare immunostaining for ghrelin and several PCs $(1 / 3,2,7$, and furin) in

Abbreviation: PC, prohormone convertase 
Table 1. Primary antibodies used in immunohistochemical analysis

\begin{tabular}{lllll}
\hline \multicolumn{1}{c}{ Antigen } & \multicolumn{1}{c}{ Code } & Host & Dilution & \multicolumn{1}{c}{ Source } \\
\hline Ghrelin & H-031-31 & Rabbit & $1: 500$ & Phoenix, Belmont, CA \\
Ghrelin & sc-10368 & Goat & $1: 50$ & Santa Cruz Biotechnology, CA \\
Preproghrelin & H-031-34 & Rabbit & $1: 500$ & Phoenix, Belmont, CA \\
Obestatin & H-031-90 & Rabbit & $1: 500$ & Phoenix, Belmont, CA \\
Glucagon & G 2654 & Mouse & $1: 500$ & Sigma, Saint Louis, MO \\
Glucagon & 4031-01F & Guinea pig & $1: 100$ & Millipore, Temacula, CA \\
Insulin & 4011-01F & Guinea Pig & $1: 500$ & Cedarlane Laboratories; ON, Canada \\
PC1/3 (EC 3.421.93) & sc-33813 & Rabbit & $1: 100$ & Santa Cruz Biotechnology, CA \\
PC2 (EC 3.421.94) & AB15610 & Rabbit & $1: 100$ & Millipore, Temacula, CA \\
PC7 (EC 3.4.21.B27) & ALX-210-217 & Rabbit & $1: 100$ & Cederlane, Burlington, ON, Canada \\
Furin (EC 3.4.21.75) & NB100-1903 & Rabbit & $1: 1000$ & Novus Biological, CO \\
\hline
\end{tabular}

PC, prohormone convertase.

stomach and pancreas in the perinatal period. We identified specific cell populations expressing preproghrelin, hormones generated from this precursor, as well as key PCs.

\section{MATERIALS AND METHODS}

Animals. Time-pregnant female Sprague-Dawley rats (Charles River Laboratories, St Constant, QU, Canada) were housed from day 13 of pregnancy in the animal care center at the Child and Family Research Institute with free access to water and to a standard diet. Dams were killed on day 21 of pregnancy, or were allowed to deliver and nurse normally. Stomach and pancreas were obtained from the fetuses at $21 \mathrm{~d}$ of gestation (embryonic day 21 ) and from the pups on postnatal days 1, 6, 13, 21, and 28. Litters (male and female) were culled to 11 neonates at postnatal day 1 to ensure similar weight gain. Tissues were fixed overnight in $4 \%$ paraformaldehyde at $4{ }^{\circ} \mathrm{C}$, rinsed in $70 \%$ ethanol, and embedded in paraffin. All experiments were approved by the University of British Columbia Animal Care Committee.

Immunohistochemistry. Five-micrometer sections were prepared for immunostaining for hormones and PCs. Sections were dewaxed and rehydrated through descending ethanol series. Antigen retrieval was performed with sodium citrate buffer $(10 \mathrm{mM})$ for $15 \mathrm{~min}$. Thereafter sections were washed three times in PBS (pH 7.4), blocked in 1\% BSA, 5\% normal goat or rabbit serum diluted in PBS with $0.3 \%$ triton $\mathrm{X}-100$ for $30 \mathrm{~min}$ and incubated with one or two primary antibodies overnight at $4^{\circ} \mathrm{C}$ (Table 1). After washing three times in PBS, sections were incubated with secondary antibodies (1:1500 dilutions) with rabbit, goat, mouse, or guinea pig specificity, as appropriate (Alexa Fluor 488, 594, Molecular Probes, Eugene, OR) for $1 \mathrm{~h}$ at room temperature and washed three times in PBS. Finally, sections were mounted with Vectashield mounting media with 4',6-diamidino-2-phenylindole (Vector Laboratories, Burlington, ON, Canada). Primary antibodies were omitted for negative controls. The specificity of the preproghrelin staining was further confirmed in the stomach by the demonstration that addition of the preproghrelin peptide to the preproghrelin antibody in the incubation mixture prevented preproghrelin staining. Images were taken with Olympus Bx5T microscope and processed with Image $\mathrm{J}$ software (http://rsb.info.nih.gov/ij/).

In situ hybridization. A synthetic oligodeoxyribonucleotide probe complementary to nucleotides 90 to 134 of rat preproghrelin mRNA was made (accession number NM 21669). This sequence has no significant similarity with any other mammalian mRNA as assessed by a Gene bank database BLAST search. The synthetic probe was modified at the $5^{\prime}$ end with digoxigenin (Integrated DNA technologies, Coralville, IA). Nonradioactive in situ hybridization was performed on 5- $\mu \mathrm{m}$ stomach paraffin sections. In brief, the sections were dewaxed in xylene and then rehydrated through decreasing ethanol series. Sections were then incubated for 15 min with PBS including $0.3 \%$ Triton X-100. After washing twice with PBS, sections were permeabilized with diethylpyrocarbonate-TE $[100 \mathrm{mM}$ tris-hydrochloric acid $(\mathrm{HCl}), 50$ mM EDTA, pH 8.0] containing $20 \mu \mathrm{g} / \mathrm{ml}$ RNase-free proteinase $\mathrm{K}$ (30 min at $37^{\circ} \mathrm{C}$ ) followed by postfixation with $4 \%$ paraformaldehyde. Sections were then washed with PBS and treated with $0.2 \mathrm{M} \mathrm{HCl}(10 \mathrm{~min})$ and acetylated with trietanolamine $+\mathrm{HCl}+$ acetic anhydride for $10 \mathrm{~min}$. After that, sections were prehybridized with the hybridization mix (deionized formamide, dextran sulfate, Denhardt's solution, sodium citrate/sodium chloride (SSC), $10 \mathrm{mM}$ dithiothreitol, $1 \mathrm{mg} / \mathrm{ml}$ yeast t-RNA) without probe for 1 to $2 \mathrm{~h}$ at $37^{\circ} \mathrm{C}$ in a moist chamber. Prehybridization mix was replaced by fresh hybridization mix containing digoxigenin labeled probe $(1 \mathrm{ng} / \mu \mathrm{l}$ in hybridization buffer) and kept overnight at $4^{\circ} \mathrm{C}$. Sections were covered with parafilm. The slides were dipped briefly in $2 \times \mathrm{SSC}$ solution to remove the parafilm followed by stringent washes twice in $2 \times$ SSC and four times in $1 \times$ SSC $(15$ min at $\left.37^{\circ} \mathrm{C}\right)$. Sections were washed in maleic acid buffer $(0.1 \mathrm{M}$ maleic acid, 0.15 $\mathrm{M}$ sodium chloride $(\mathrm{NaCl}), \mathrm{pH} 7.5$, and $0.3 \%$ Tween-20) for $5 \mathrm{~min}$ and blocked with $1 \times$ blocking solution $(900 \mu \mathrm{L}$ maleic acid buffer $+100 \mu \mathrm{L} 10 \%$ blocking reagent) for $1 \mathrm{~h}$ at room temperature. Sections were incubated with sheep antidigoxigenin Fab fragments conjugated to alkaline phosphatase (1 $\mu \mathrm{L} / 1000 \mu \mathrm{L}$ blocking solution) overnight at $4^{\circ} \mathrm{C}$. Finally, sections were washed with washing buffer twice for $15 \mathrm{~min}$ each, incubated in detection buffer $(0.1 \mathrm{M}$ tris-HCl, $0.1 \mathrm{M} \mathrm{NaCl}, \mathrm{pH} 9.5)$ for $5 \mathrm{~min}$. Color substrate $(20 \mu \mathrm{L}$ $50 \times 5$-bromo-4-chloro- $3^{\prime}$-indolyphosphate $p$-toluidine salt/nitro-blue tetrazolium chloride $+980 \mu \mathrm{L}$ detection buffer) was added to the sections to develop blue black precipitate at the site of hybridization. Sections were kept covered from light at $4^{\circ} \mathrm{C}$ for 12 to $48 \mathrm{~h}$. Bright field pictures were taken on a phase contrast microscope.

Statistics. Data are reported as mean $( \pm$ SEM). Differences between groups were assessed by ANOVA for repeated measured followed by post hoc analysis using least significant difference. A $p$ value $<0.05$ was regarded as significant. Data were analyzed with SPSS version 15.0 (2006, SPSS Inc., Chicago, IL).

\section{RESULTS}

Preproghrelin, ghrelin, obestatin, and PCs in stomach. Preproghrelin immunoreactive cells were abundant in the stomach at embryonic day 21 . Their number remained stable during the first 2 wk of life and increased by postnatal day 21 and postnatal day 28 (Fig. 1 and Table 2). Similar patterns for preproghrelin were demonstrated by in situ hybridization (performed at embryonic day 21 and postnatal day 28) and immunofluorescence (Fig. 1). In contrast, ghrelin immunoreactive cells were rare at embryonic day 21 and their number increased progressively until weaning (Fig. 1 and Table 2). Identical results were obtained using two different ghrelin antibodies (Table 1). Most preproghrelin immunoreactive cells were negative for ghrelin and obestatin, but all ghrelin positive cells were positive for obestatin and preproghrelin (Figs. 1 and 2).

PC1/3 immunoreactivity was present in all ghrelin positive cells and vice versa. Similar to ghrelin, $\mathrm{PC} 1 / 3$ staining increased with age (Fig. 3). Furin was found in the glandular part of the stomach from postnatal days 21 to 28 , but was absent from embryonic day 21 till postnatal day 13 and was observed in ghrelin positive as well as in ghrelin negative cells (data not shown). Immunoreactivity for PC2 and PC7 was not detected in the stomach (data not shown).

Preproghrelin, ghrelin, obestatin, insulin, and glucagon in pancreatic islets. In pancreas, there were 0 to 2 preproghrelin positive cells in the periphery of most islets from embryonic day 21 to postnatal day 13 after which they became 

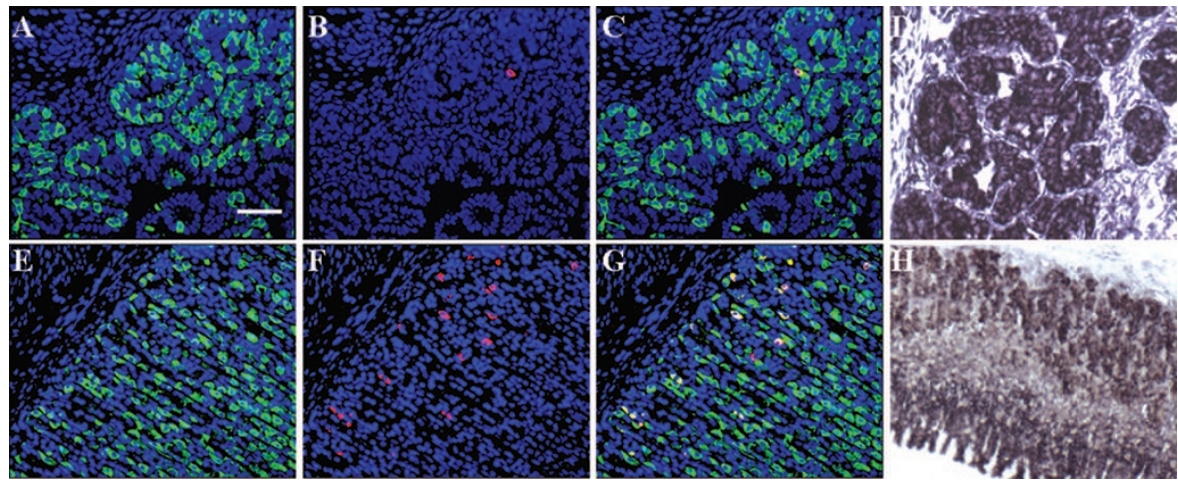

Figure 1. Ghrelin and preproghrelin immunoreactivity in rat stomach. Immunostaining for preproghrelin $(A$ and $E$, green), ghrelin $(B$ and $F$, red) with 4',6-diamidino-2-phenylindole (DAPI) (blue), and merged ( $C$ and $G$, yellow) in the stomach shown at embryonic day $21(A-C)$ and postnatal day 28 ( $E-G)$. Preproghrelin positive cells were abundant in the stomach from embryonic day 21 until postnatal day 28 . In contrast, ghrelin cells were rare at embryonic day 21 and their number increased progressively from embryonic day 21 to postnatal day 28. All ghrelin cells were positive for preproghrelin at all ages. In situ hybridization for ghrelin mRNA in rat stomach at embryonic day $21(D)$ and postnatal day $28(H)$. Preproghrelin mRNA was abundant in the glandular part of the stomach. Magnification, $\times 200$; bar represents $10 \mu \mathrm{m}$.

Table 2. Ontogeny of preproghrelin $(P P G)$, ghrelin $(G H R)$, and obestatin $(O B)$ positive cells by immunohistochemistry in the perinatal rat stomach

\begin{tabular}{|c|c|c|c|c|c|c|}
\hline Age (d) & E21 & PND1 & PND6 & PND13 & PND21 & PND28 \\
\hline PPG $(+)($ cells/field $)$ & $159(15)$ & $147(11)$ & $153(13)$ & $175(11)$ & $342(31)^{*}$ & $412(35)^{*} \dagger$ \\
\hline GHR $(+) / \mathrm{OB}(+)($ cells/field $)$ & $1(0)$ & $1(0)$ & $3(1)$ & $6(0)$ & $16(2)^{*}$ & $23(3) * \dagger$ \\
\hline$\%$ GHR $(+)$ or $\mathrm{OB}(+) / \mathrm{PPG}$ cells & $0.5(0.1)$ & $0.9(0.2)$ & $1.9(0.6)$ & $3.6(0.5)$ & $4.5(0.2)^{*}$ & $5.7(1.3)^{*}$ \\
\hline
\end{tabular}

Each value is the mean of three different animals. In each animal, the no. cells was counted in seven different sections and averaged. Mean (SEM), $p<0.001$ (ANOVA) for each variable.

$* p<0.05$ compared with E21, PND1, and PND6.

$\dagger p<0.05$ compared with PND21.

E, embryonic; PND, postnatal day.
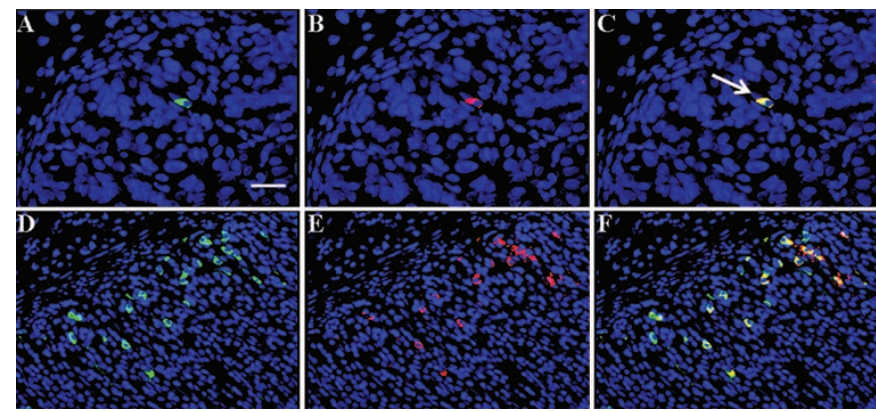

Figure 2. Ghrelin and obestatin in rat stomach. Immunostaining for obestatin ( $A$ and $D$, green) and ghrelin ( $B$ and $E$, red) with $4^{\prime}, 6$-diamidino2-phenylindole ( $D A P I)$ (blue), and merged ( $C$ and $F$, yellow) at embryonic day $21(A-C)$ and postnatal day $21(D-F)$. All ghrelin cells colocalized with obestatin cells at both time points. Magnification, $\times 200$; bar represents $10 \mu \mathrm{m}$.

almost undetectable (Fig. 4). In situ hybridization performed at postnatal day 6 confirmed the small number of islet cells that contained preproghrelin mRNA (Data not shown). In contrast to the stomach, all preproghrelin positive cells were also ghrelin positive and obestatin positive in the pancreas (Fig. 4).

To characterize further the ghrelin positive cells in the pancreas, we performed double immunofluorescence with ghrelin and insulin or glucagon. Insulin and ghrelin did not colocalize at any developmental stage (Fig. 5). In contrast, using a glucagon antibody that was specific for mature glucagon, we observed that the ghrelin positive cells were either
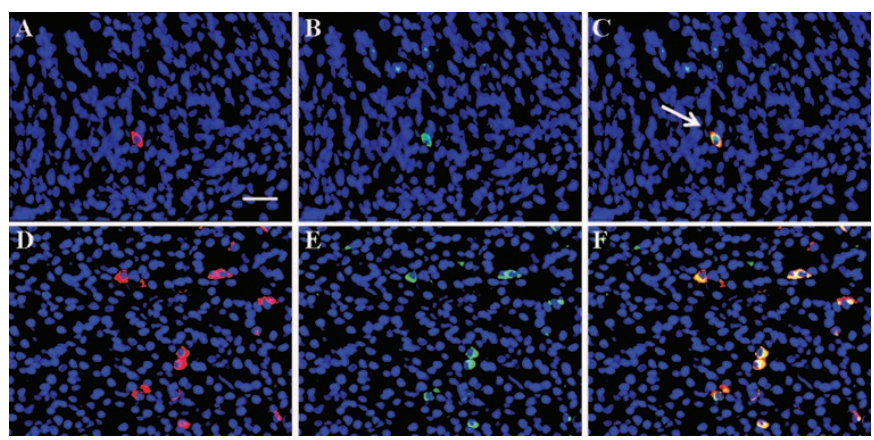

Figure 3. Ghrelin and $\mathrm{PC} 1 / 3$ in rat stomach. Immunostaining for ghrelin $(A$ and $D$, red) and $\mathrm{PC} 1 / 3$ ( $B$ and $E$, green) with $4^{\prime}, 6$-diamidino-2-phenylindole $(D A P I)$ (blue), and merged ( $C$ and $F$, yellow) at postnatal day $6(A-C)$ and postnatal day $28(D-F)$ in the rat stomach. All ghrelin cells colocalized with PC1/3. Magnification, $\times 200$; bar represents $10 \mu \mathrm{m}$.

glucagon negative (so called $\varepsilon$-cells) or glucagon positive (Fig. 5). To test the hypothesis that these ghrelin positive/ glucagon negative cells might contain unprocessed proglucagon, we stained adjacent sections with ghrelin and either a glucagon antibody that recognizes only mature glucagon or one that recognizes both mature glucagon and proglucagon (18). Ghrelin positive cells that were negative for glucagon were also negative for proglucagon (data not shown).

As expected, islet $\beta$-cells intensely stained for $\mathrm{PC} 1 / 3$, an enzyme essential for proinsulin processing. $\mathrm{PC} 2$, required for the processing of proglucagon to mature glucagon as well as for proinsulin processing, was present in most insulin positive $\beta$-cells and all glucagon positive $\alpha$-cells (data not shown). 


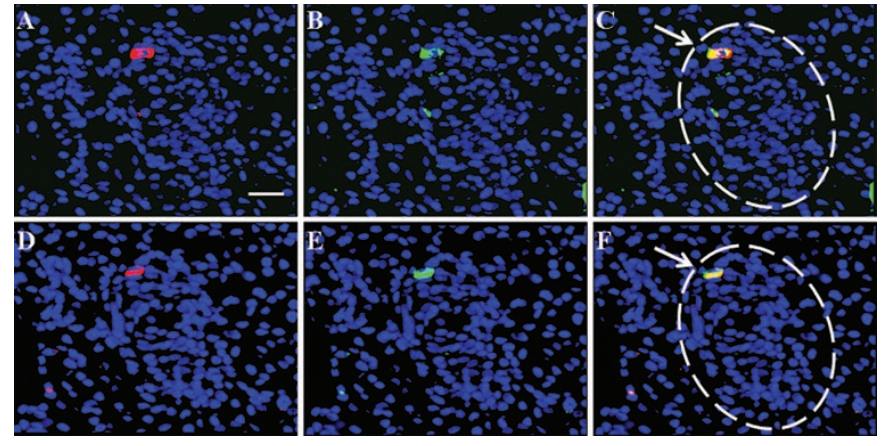

Figure 4. Preproghrelin, ghrelin, and obestatin in rat pancreas. Two adjacent sections of the pancreas were stained on postnatal day 1 . The first section was double stained for ghrelin and preproghrelin [ghrelin ( $A$, red), preproghrelin ( $B$, green) with 4',6-diamidino-2-phenylindole (DAPI) (blue), and merged ( $C$, arrow, yellow)]. The second section was stained for ghrelin and obestatin [ghrelin $(D$, red) obestatin ( $E$, green) with DAPI (blue), and merged ( $F$, arrow, yellow)]. The islet boundary is shown by dotted lines. The results of the adjacent sections show that ghrelin cells colocalized with both preproghrelin and obestatin. Magnification, $\times 200$; bar represents $10 \mu \mathrm{m}$.
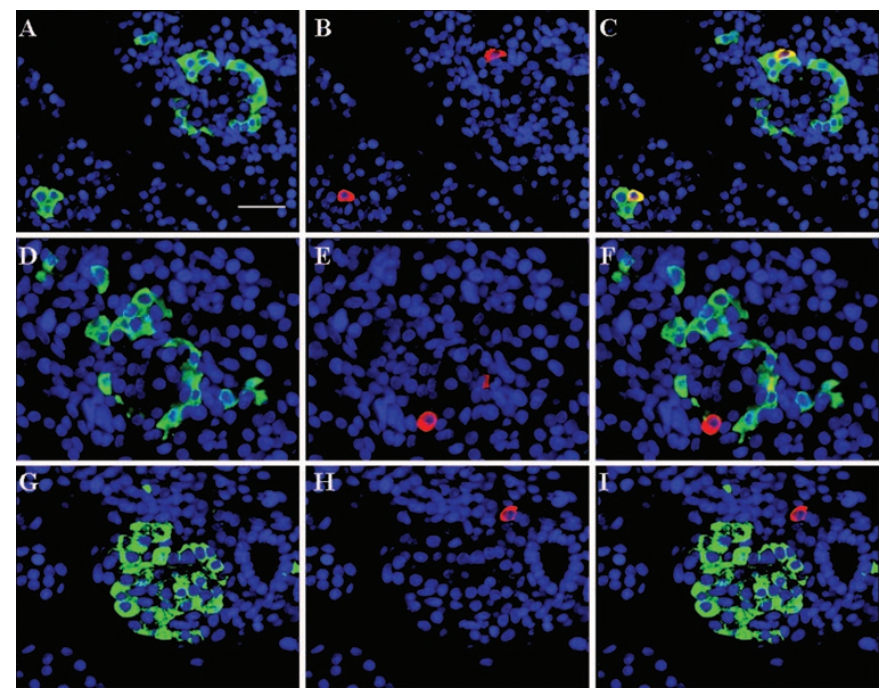

Figure 5. Ghrelin, glucagon, and insulin in rat pancreas. Immunohistochemical localization of ghrelin (red) with glucagon (green) and 4',6-diamidino2-phenylindole (DAPI) (blue) at postnatal day 13. Ghrelin colocalized with glucagon $(A-C)$ but was also present as an independent cell type with no glucagon costaining $(\varepsilon$-cell) $(D-F)$. Ghrelin did not colocalize with insulin $(G-I)$. Magnification $\times 200$; bar represents $10 \mu \mathrm{m}$.

PC1/3 was found to be colocalized with some but not all ghrelin positive cells (Fig. 6). Similarly, some but not all ghrelin positive cells were also positive for PC2 (Fig. 6). Furin was found in the $\beta$-cells but not in any glucagon or ghrelin positive cells (data not shown). We did not observe any staining for PC7 in the pancreatic islets.

\section{DISCUSSION}

This report identifies marked differences in the ontogeny of ghrelin-containing cells in rat pancreas and stomach. In addition, we describe for the first time the relationship between the immunostaining of specific PCs and of ghrelin in the perinatal pancreas and stomach. This work represents an important step toward the understanding of preproghrelin protein expression and processing in the prenatal and neonatal states.
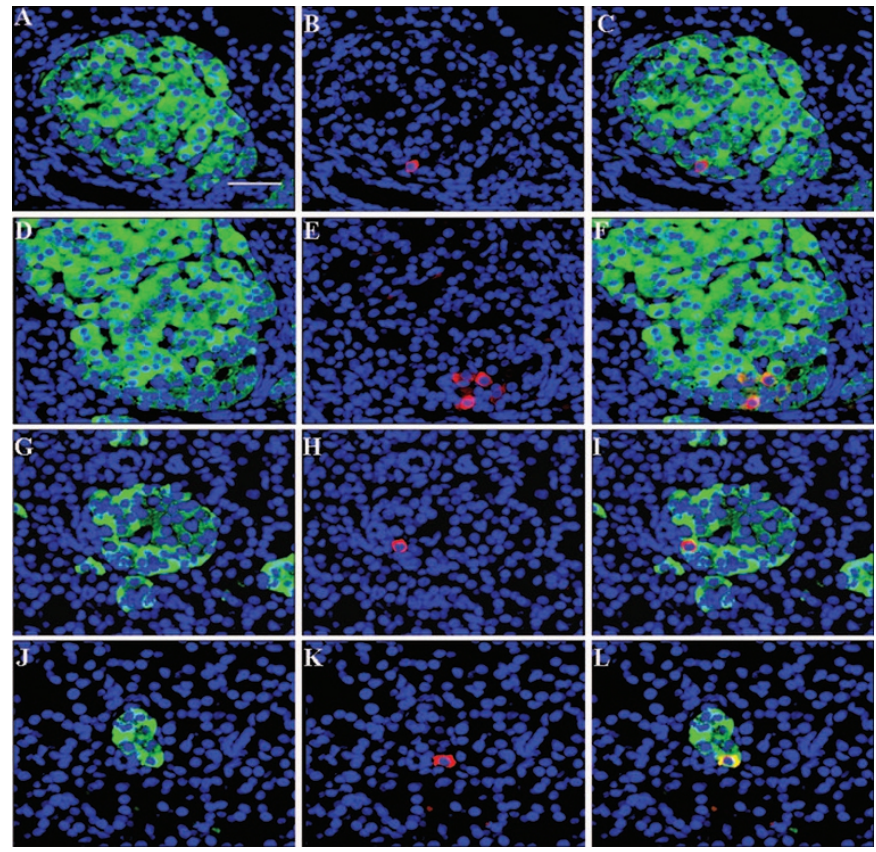

Figure 6. Ghrelin, $\mathrm{PC} 1 / 3$ and $\mathrm{PC} 2$ in rat pancreas. Double immunostaining for PC1/3 ( $A$ and $D$, green) and ghrelin ( $B$ and $E$, red) with $4^{\prime}, 6$-diamidino2-phenylindole $(D A P I)$ (blue) at postnatal day 13 in the pancreas. Islet cells that were positive for ghrelin were either negative $(C)$ or positive for $\mathrm{PC} 1 / 3$ ( $F$, yellow). Immunostaining for PC2 ( $G$ and $J$, green) and ghrelin ( $H$ and $K$, red) with $D A P I$ (blue) at postnatal day 13 in the rat pancreas. Similar to $\mathrm{PC} 1 / 3$, we observed ghrelin positive cells that were negative $(I)$ and positive ( $L$, yellow) for PC2. Magnification, $\times 200$; bar represents $10 \mu \mathrm{m}$.

Ghrelin is mainly produced in the oxyntic mucosa of the stomach in adult rats (19). Accordingly, we observed immunostaining for preproghrelin and ghrelin almost exclusively in the glandular part of the perinatal stomach. Preproghrelin positive cells were 18 to 160 times more abundant than ghrelin positive cells, depending on the age. The number of ghrelin positive cells, expressed as percent of preproghrelin positive cells, also increased progressively from embryonic day 21 to weaning, a finding consistent with the increase in the tissue concentrations of immunoreactive acylated and total ghrelin previously reported by our group in the rat fetus and neonate (16). The reason for this progressive increase in the processing of preproghrelin to ghrelin after birth is unclear. Ghrelin increases body weight by stimulating food intake [a mechanism that is, however, not functional in the rat neonate because of brain immaturity (20)] and decreasing fat utilization (21). We hypothesize that the progressive increase in ghrelin release in the early postnatal period could represents an adaptation to the extrauterine environment and corresponds to an attempt by the neonate to decrease fat utilization and favor weight gain. Our current results differ from the study by Zhao et al. (22), performed in the same strain of rats and using the same antibodies, who found a similar number of preproghrelin positive and ghrelin positive cells in the stomach up to postnatal day 6 and only a modest excess of preproghrelin positive cells thereafter. The exact reason for this discrepancy is unclear, but may be related to differences in methodology. However, in the present study, the identity of the ghrelin positive cells was confirmed using two different antibodies, 
the abundance of preproghrelin was confirmed by in situ hybridization and the specificity of preproghrelin staining was further supported by the demonstration that addition of preproghrelin peptide in the incubation mixture prevented the staining. Taken together, our results help define the abundance and age-dependence of ghrelin expression and processing in the stomach.

PCs are a group of enzymes that cleave propeptides at the $\mathrm{C}$ terminus of basic doublets (23). Processing of preproghrelin in the stomach is thought to be mediated by PC1/3, but not by PC2 (2). Consistent with these findings, we observed that PC1/3 immunostaining increased progressively from embryonic day 21 to postnatal day 28 and always colocalized with ghrelin (and vice versa). Because ghrelin colocalizes with obestatin (Fig. 2) and because preproghrelin is consistently much more abundant than ghrelin in the stomach (Fig. 1), it implies that $\mathrm{PC} 1 / 3$ is only present in the preproghrelin negative and ghrelin/obestatin positive cells. These data suggest that the posttranslational processing of preproghrelin may be the limiting factor for mature ghrelin release in this tissue. PC2 immunostaining was not found in the stomach. We also investigated the possible association between immunostaining for ghrelin and two other basic amino acid specific PCs, furin and PC7. Both convertases have recently been shown to generate mature ghrelin from preproghrelin in vitro (24). We observed furin immunostaining in the stomach from postnatal day 21, but furin did not always colocalize with preproghrelin positive or ghrelin positive cells. PC7 was not found in the stomach. Taken together, these data support a primary role for $\mathrm{PC} 1 / 3$ in the processing of preproghrelin in the stomach, where it may serve as a limiting step for the processing of preproghrelin to ghrelin.

In pancreas, the identity of the ghrelin-secreting cells remains controversial. Immunostaining for ghrelin was observed in $\beta$-cells (25), in $\alpha$-cells (12), and in a newly discovered type of cell, that does not stain for any of the known islet hormones, and called the $\varepsilon$-cell $(13,14,26)$. Recent work has emphasized the complexity of the pathways leading to the differentiation of ghrelin producing cells. Loss of function of $\mathrm{nkx} 2.2$, a transcription factor required for the differentiation of all $\beta$-cells and some $\alpha$-cells, causes a marked increase in the number of $\varepsilon$-cells, suggesting that all three cell types share a common progenitor (13). Several transcription factors differentially affect the development of ghrelin-producing $\alpha$ - and $\varepsilon$-cells. For instance, disruption of Pax 4, a transcription factor expressed in all islet cell type in the fetus, increases the number of ghrelin/glucagon positive cells without affecting the number of ghrelin positive/glucagon negative cells $(26,27)$. The complex interaction of the transcription factors involved in the specification of the fate of islet cells is presently the focus of intense research.

We did not detect ghrelin immunostaining in $\beta$-cells. In contrast, using two different antibodies, we observed ghrelin immunostaining either independently of glucagon staining or together with glucagon immunostaining in a minority of $\alpha$-cells. This supports the concept that there are two different ghrelin producing cell types in the pancreas $(13,28)$. To further characterize the differences between ghrelin/glucagon positive and ghrelin positive/glucagon negative cells, we tested the hypothesis that $\varepsilon$-cells could contain unprocessed proglucagon. Using two different glucagon antibodies (one that recognizes only mature glucagon and one that recognizes both glucagon and proglucagon), we observed that ghrelin positive cells that were negative for glucagon were also negative for proglucagon suggesting that $\varepsilon$-cells do not contain unprocessed proglucagon.

In the pancreas, we found few preproghrelin positive cells at the periphery of the islets and they decreased in frequency with advancing age. Preproghrelin and ghrelin cells were always colocalized with each other, suggesting that processing of preproghrelin into ghrelin takes place in each preproghrelin positive cell. The low level of expression of preproghrelin in the pancreas was confirmed by the demonstration of small amounts of preproghrelin mRNA by in situ hybridization. We again observed similar results for ghrelin immunoreactivity by using two different antibodies. Our results strongly suggest that ghrelin is expressed in a relatively small subset of islet cells.

We then investigated which PCs colocalized with ghrelinproducing cells in the pancreatic islets. $\mathrm{PC} 1 / 3$ immunostaining was found in all $\beta$-cells, consistent with the role of this enzyme in proinsulin processing. $\mathrm{PC} 1 / 3$ was also observed in ghrelin positive cells but in contrast to the stomach, not all ghrelin positive cells were positive for PC $1 / 3$, suggesting that in pancreas, preproghrelin is not processed exclusively by $\mathrm{PC} 1 / 3$. Some of the ghrelin positive cells in the pancreas were also PC2 positive, suggesting that PC2 may play a role in preproghrelin processing in this tissue. However, Zhu et al. (2) demonstrated that at least in stomach, PC2 does not contribute to preproghrelin processing. We also investigated whether furin or PC7 were present in ghrelin positive cells in pancreatic islets. We observed furin immunostaining in $\beta$-cells (29) but not in the ghrelin positive cells. We did not observe PC7 immunostaining in pancreas. Together, these data implicate $\mathrm{PC} 1 / 3$ and PC2 but not furin or PC7 in preproghrelin processing.

Obestatin is purported to be a biologically active peptide that is also encoded by the preproghrelin gene. If obestatin is truly secreted as an independent peptide following preproghrelin processing, it would be expected that each molecule of preproghrelin would generate one molecule of ghrelin and one molecule of obestatin. In the present study, using an antibody that recognizes only full length obestatin and does not cross react with preproghrelin, we show that obestatin immunostaining is present in each ghrelin positive cell in both stomach and pancreas, supporting the possibility that preproghrelin can generate both ghrelin and obestatin. Similar results were obtained by Zhao et al. (22) although immunostaining for obestatin tended to be more abundant than for ghrelin. In humans, Gronberg et al. (17) also observed colocalization of ghrelin with obestatin in the pancreas islet, although the specific cell types in which these peptides were present was not identified. However, we have previously reported that both tissue and plasma concentrations of obestatin are much lower than those of ghrelin (16). This discrepancy could reflect incomplete preproghrelin processing in the tissues or rapid degradation of the obestatin. 
In summary, we show that the progressive increase in the stomach expression of ghrelin is likely due to an increase in the processing of preproghrelin, whereas the decrease in the pancreas expression of ghrelin is associated with a decrease in the expression of preproghrelin. Our data are also consistent with the demonstration in PC1/3 knock out animals (2) that $\mathrm{PC} 1 / 3$ is the major PC mediating preproghrelin processing in the stomach. In contrast, our data suggest that both $\mathrm{PC} 1 / 3$ and PC2 play a role in preproghrelin processing in the developing pancreas and therefore in the local release of ghrelin.

Acknowledgments. The authors thank Alfred Wong (Laboratory technician) for help with tissue collection and Hehong $\mathrm{Ni}$ (Post Doctoral Fellow) for useful discussions. In addition, the authors acknowledge the gift of glucagon antibody from Dr. Bruce Verchere, CFRI, Vancouver.

\section{REFERENCES}

1. van der Lely AJ, Tschop M, Heiman ML, Ghigo E 2004 Biological, physiological, pathophysiological, and pharmacological aspects of ghrelin. Endocr Rev 25:426457

2. Zhu X, Cao Y, Voogd K, Steiner DF 2006 On the processing of proghrelin to ghrelin. J Biol Chem 281:38867-38870

3. Chanoine JP 2005 Ghrelin in growth and development. Horm Res 63:129-138

4. Zhang JV, Ren PG, Avsian-Kretchmer O, Luo CW, Rauch R, Klein C, Hsueh AJ 2005 Obestatin, a peptide encoded by the ghrelin gene, opposes ghrelin's effects on food intake. Science 310:996-999

5. Chanoine JP, Wong AC 2004 Ghrelin gene expression is markedly higher in fetal pancreas compared with fetal stomach: effect of maternal fasting. Endocrinology 145:3813-3820

6. Dezaki K, Sone H, Yada T 2008 Ghrelin is a physiological regulator of insulin release in pancreatic islets and glucose homeostasis. Pharmacol Ther 118:239-249

7. Reimer MK, Pacini G, Ahren B 2003 Dose-dependent inhibition by ghrelin of insulin secretion in the mouse. Endocrinology 144:916-921

8. Granata R, Settanni F, Gallo D, Trovato L, Biancone L, Cantaluppi V, Nano R, Annunziata M, Campiglia P, Arnoletti E, Ghe C, Volante M, Papotti M, Muccioli G, Ghigo E 2008 Obestatin promotes survival of pancreatic beta-cells and human islets and induces expression of genes involved in the regulation of beta-cell mass and function. Diabetes 57:967-979

9. Ren AJ, Guo ZF, Wang YK, Wang LG, Wang WZ, Lin L, Zheng X, Yuan WJ 2008 Inhibitory effect of obestatin on glucose-induced insulin secretion in rats. Biochem Biophys Res Commun 369:969-972

10. Gourcerol G, St-Pierre DH, Tache Y 2007 Lack of obestatin effects on food intake: should obestatin be renamed ghrelin-associated peptide (GAP)? Regul Pept 141:1-7
11. Zhu X, Orci L, Carroll R, Norrbom C, Ravazzola M, Steiner DF 2002 Severe block in processing of proinsulin to insulin accompanied by elevation of des-64,65 proinsulin intermediates in islets of mice lacking prohormone convertase $1 / 3$. Proc Natl Acad Sci USA 99:10299-10304

12. Date Y, Nakazato M, Hashiguchi S, Dezaki K, Mondal MS, Hosoda H, Kojima M, Kangawa K, Arima T, Matsuo H, Yada T, Matsukura S 2002 Ghrelin is present in pancreatic alpha-cells of humans and rats and stimulates insulin secretion. Diabetes 51:124-129

13. Prado CL, Pugh-Bernard AE, Elghazi L, Sosa-Pineda B, Sussel L 2004 Ghrelin cells replace insulin-producing beta cells in two mouse models of pancreas development. Proc Natl Acad Sci USA 101:2924-2929

14. Wierup N, Yang S, McEvilly RJ, Mulder H, Sundler F 2004 Ghrelin is expressed in a novel endocrine cell type in developing rat islets and inhibits insulin secretion from INS-1 (832/13) cells. J Histochem Cytochem 52:301-310

15. Portela-Gomes GM, Grimelius L, Stridsberg M 2008 Prohormone convertases 1/3, 2 , furin and protein 7B2 (Secretogranin V) in endocrine cells of the human pancreas. Regul Pept 146:117-124

16. Chanoine JP, Wong AC, Barrios V 2006 Obestatin, acylated and total ghrelin concentrations in the perinatal rat pancreas. Horm Res 66:81-88

17. Gronberg M, Tsolakis AV, Magnusson L, Janson ET, Saras J 2008 Distribution of Obestatin and Ghrelin in Human Tissues: Immunoreactive Cells in the Gastrointestinal Tract, Pancreas, and Mammary Glands. J Histochem Cytochem (in press)

18. Wang J, Xu J, Finnerty J, Furuta M, Steiner DF, Verchere CB 2001 The prohormone convertase enzyme 2 (PC2) is essential for processing pro-islet amyloid polypeptide at the NH2-terminal cleavage site. Diabetes 50:534-539

19. Kojima M, Hosoda H, Date Y, Nakazato M, Matsuo H, Kangawa K 1999 Ghrelin is a growth-hormone-releasing acylated peptide from stomach. Nature 402:656-660

20. Grove KL, Cowley MA 2005 Is ghrelin a signal for the development of metabolic systems? J Clin Invest 115:3393-3397

21. Tschop M, Smiley DL, Heiman ML 2000 Ghrelin induces adiposity in rodents Nature 407:908-913

22. Zhao CM, Furnes MW, Stenstrom B, Kulseng B, Chen D 2008 Characterization of obestatin- and ghrelin-producing cells in the gastrointestinal tract and pancreas of rats: an immunohistochemical and electron-microscopic study. Cell Tissue Res 331:575-587

23. Bataille D 2007 Pro-protein convertases in intermediary metabolism: islet hormones, brain/gut hormones and integrated physiology. J Mol Med 85:673-684

24. Ozawa A, Cai Y, Lindberg I 2007 Production of bioactive peptides in an in vitro system. Anal Biochem 366:182-189

25. Volante M, Allia E, Gugliotta P, Funaro A, Broglio F, Deghenghi R, Muccioli G, Ghigo E, Papotti M 2002 Expression of ghrelin and of the GH secretagogue receptor by pancreatic islet cells and related endocrine tumors. J Clin Endocrinol Metab $87: 1300-1308$

26. Heller RS, Jenny M, Collombat P, Mansouri A, Tomasetto C, Madsen OD, Mellitzer G, Gradwohl G, Serup P 2005 Genetic determinants of pancreatic epsilon-cell development. Dev Biol 286:217-224

27. Wang Q, Elghazi L, Martin S, Martins I, Srinivasan RS, Geng X, Sleeman M, Collombat P, Houghton J, Sosa-Pineda B 2008 Ghrelin is a novel target of Pax4 in endocrine progenitors of the pancreas and duodenum. Dev Dyn 237:51-61

28. Wierup N, Svensson H, Mulder H, Sundler F 2002 The ghrelin cell: a novel developmentally regulated islet cell in the human pancreas. Regul Pept 107:63-69

29. Kayo T, Konda Y, Tanaka S, Takata K, Koizumi A, Takeuchi T 1996 Developmental expression of proprotein-processing endoprotease furin in rat pancreatic islets. Endocrinology 137:5126-5134 